\title{
APLIKASI BANTU BUTA WARNA BERBASIS ANDROID
}

\author{
Zanudin Husain ${ }^{1}$, Syafruddin Syarif ${ }^{2}$, Abdul Latif Arda ${ }^{3}$, Andryanto Aman ${ }^{4}$ \\ ${ }^{1}$ Politeknik Gorontalo \\ ${ }^{2}$ Universitas Hasanuddin \\ ${ }^{3}$ STMIK Handayani Makassar \\ ${ }^{4}$ STMIK AKBA Makassar \\ Email: ${ }^{1}$ zainudin@ @oligon.ac.id, ${ }^{2}$ ssyariftuh376@gmail.com, ${ }^{3}$ latiefarda@ gmail.com, ${ }^{4}$ andryanto@akba.ac.id
}

(Naskah masuk: 19 Februari 2020, diterima untuk diterbitkan: 4 April 2020)

\begin{abstract}
Abstrak
Tujuan dari penelitian ini membuat aplikasi kecerdasan buatan yang dapat identifikasi masalah dalam penglihatan yaitu buta warna dan deteksi objek warna yang memungkinkan seorang penderita buta warna dapat mengetahui dirinya tersebut mengalami buta warna tertentu (parsial) atau teridentifikasi buta warna total sehingga seseorang yang mengalami masalah penglihatan dapat menyesuaikan dirinya dalam menjalani kehidupan sehari-hari dengan baik, aplikasi ini dibuat pada sistem operasi android dengan memanfaatkan library Open CV dan implementasi nilai HSV (Hue, Saturation, Value) untuk deteksi objek dan motode ishihara yang telah disediakan dalam aplikasi untuk identifikasi jenis buta warna menggunakan gambar angka yang berwarna sebanyak 12 dan 21 plat. $100 \%$ aplikasi dapat mendeteksi warna merah, jingga, kuning, biru, hijau, dan ungu. hasil uji coba pengguna dari aplikasi ini menyatakan bahwa aplikasi tersebut sangat bermanfaat bagi orang yang memiliki gangguan penglihatan khususnya buta warna parsial sebagai aplikasi bantu dalam mengenali objek melalui warna objek dan dapat membantu mengetahui penderita tersebut masuk dalam kategori buta warna parsial.
\end{abstract}

Kata kunci: Android, Buta Warna, HSV, Ishihara, Kecerdasan Buatan, Open CV

\section{ANDROID-BASED COLOR BLIND ASSISTIVE APPLICATION}

\begin{abstract}
The purpose of this research is to create artificial intelligence applications that can identify problems in vision: color blindness and colour object detection that allow a color blind sufferer to know that they are experiencing color blindness Or unidentified total colour blindness so that someone who is experiencing vision problems can adapt itself in living the daily life well, the application is made on the Android operating system with Utilizing the Open CV Library and implementation of HSV (Hue, Saturation, value) values for object detection and methods Ishihara that have been provided in-app for identification of color blindness types using a color figure of 12 and 21 plates. $100 \%$ of applications can detect red, orange, yellow, blue, green, and violet colors. The user's test results of the application indicate that the application is very useful for people who have impaired vision especially partial color blindness as an auxiliary application in recognizing objects through the color of the object and can help In the category of partial color blindness.
\end{abstract}

Keywords: Android, Artificial Intelligence, Color blindness, HSV, Ishihara, Open CV

\section{PENDAHULUAN}

Buta warna adalah ketidakmampuan melihat atau membedakan warna tertentu, gangguan penglihatan bisa terjadi pada siapa saja, termasuk anak-anak. Sebagian besar pengidap buta warna telah mengalaminya sejak kecil, sehingga kondisi ini sering dianggap sebagai bawaan lahir atau genetik. selain faktor genetik beberapa kondisi juga menjadi penyebab buta warna diantaranya, penyakit, usia, terpapar bahan kimia, efek samping obat-obatan[1].
Orang yang mengalami buta warna akan menghambat aktivitas hariannya, karna kesulitan melihat warna merah, hijau, biru, atau campuran warna-warna ini. Buta warna tertentu atau sebagian warna, juga bagian dari buta warna parsial.

Buta warna parsial dibagi menjadi 2 kategori, ada yang buta warna merah-hijau dan ada buta warna birukuning. beberapa jenis buta warna merah-hijau yaitu protanopia , protamali, deuteranomali, dan deuteranopia. sedangkan buta warna biru-kuning yaitu tritanomali dan tritanopia[2]. 
Cara pemeriksaan yang dapat dilakukan sebagai tes buta warna parsial diantaranya Tes ishihara , Anomaloscope, Tes benang wol berwarna. dari ketiga metode tersebut yang sering digunakan adalah Tes ishihara karna pemeriksaan ini lebih praktis dan tidak membutuhkan peralatan medis yang rumit [3]. Tes ishihara berupa kartu atau buku yang memuat gambar berwarna yang membentuk pola seperti angka, huruf, simbol, maupun alur.

beberapa penelitian yang melakukan identifikasi buta warna diantaranya penelitian melakukan pengujian jenis buta warna metode ishihara yang diterapkan pada android [4]. hasil dari penelitian dapat mengidentifikasi mata normal, buta warna parsial dan buta warna total. Kemudian penelitian lain melakukan identifikasi buta warna menggunakan sistem pakar [5]. penelitian ini menggunakan plat ishihara yang diubah menjadi gambar bangun ruang hasilnya plat perubahan dengan bangun ruangan dapat mengidentifikasikan buta warna yang tidak dapat dideteksi oleh plat isihara. Selanjutnya penelitian menebak warna pada marker kemudian menampilkan hasil tebakan dengan scan marker yang telah ditebak [6]. Kurangnya warna objek yang ditampilkan menjadi kekurangan pada penelitian ini. Penelitian lain mengenai deteksi warna adalah deteksi kematangan buah tomat berdasarkan fitur warna menggunakan metode transformasi ruang warna HIS, yang mampu mendeteksi kematangan buah tomat sehingga mempermudah dalam indentifikasi kematangan buah tomat berdasarkan warna citra kulit tomat [7]. penelitian serupa identifikasi warna dengan cara menampilkan informasi warna ke dalam teks. informasi warna video digital masih berbentuk model warna YCbCr yang kemudian dikonversi dengan nilai RGB yang tersimpan pada program [8]. Penelitian Implementasi Metode RGB To HSV pada Aplikasi Pengenalan Mata Uang Kertas Berbasis Android untuk tuna netra, aplikasi ini mampu mendeteksi mata uang kertas indonesia dengan memberikan suara dalam bahasa indonesia tentang nilai uang kertas yang terdeteksi [9].

Berdasarkan dari beberapa penelitian sebelumnya penulis membuat aplikasi bantu buta warna berbasis android dengan beberapa fitur gabungan seperti dapat mengindetifikasi jenis buta warna dan dapat mendeteksi objek warna merah, kuning, hijau, jingga, biru, dan ungu. Dengan adanya fitur deteksi jenis buta warna dan identifikasi buta warna menjadi pembeda dari penelitian sebelumnya yang hanya melakukan identifikasi buta warna. Diharapkan menjadi aplikasi bantu yang dapat bermanfaat.

\section{METODE}

Pembuatan aplikasi ini fokus pada identifiksai jenis buta warna parsial dengan menggunakan warna pada angka dan metode ishihara, selain itu aplikasi dapat juga menjadi alat bantu bagi pengguna aplikasi yang mengalami buta warna untuk mendeteksi warna objek disekitarnya.

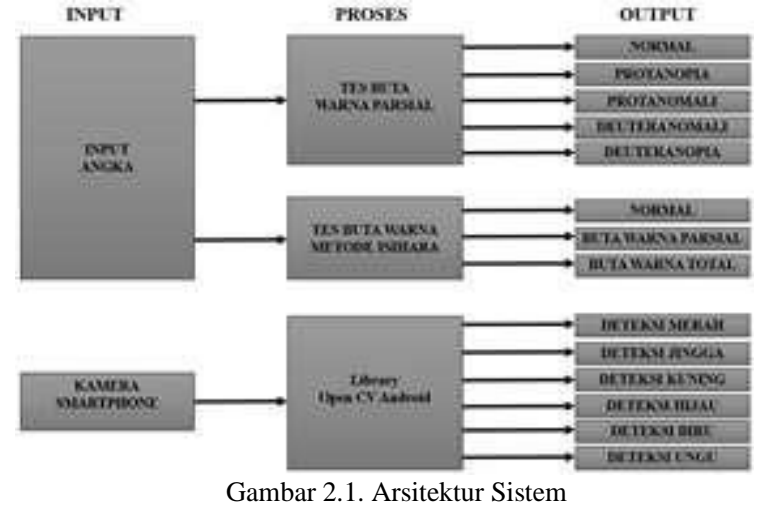

Gambar 2.1 merupakan arsitektur dari sistem, ada 2 inputan pada arsitektur sistem, inputan pertama untuk identifikasi buta warna menggunakan tes buta warna parsial atau menggunakan tes buta warna ishihara, hasil tes buta warna parsial akan mengeluarkan pemberitahuan kepada pengguna seperti mata normal, atau mengalami buta warna jenis protanopia, protanomali, deuteranomali, serta deuteranopia. Untuk mendeteksi warna, inputan yang digunakan kamera smartphone, deteksi akan dilakukan secara real-time.

\subsection{Perancangan Tes Buta Warna Parsial}

Identifikasi buta warna menggunakan warna pada angka berdasarkan jenis-jenis buta warna parsial yaitu Protanopia, Protanomali, Deuteranomali, Deuteranopia. Menurut dr. Kevin Adrian [2]. jika seseorang melihat warna merah tampak seperti warna hitam maka identifikasinya Protanopia, jika melihat warna jingga, kuning, dan merah, menjadi warna hijau adalah Protanomali, melihat warna merah menjadi kuning kecokelatan dan warna hijau menjadi krem adalah Deuteranopia, dan melihat warna hijau dan kuning tampak seperti merah dan Pengidapnya juga sulit membedakan antara ungu dan biru merupakan jenis buta warna Deuteranomali

Aplikasi ini mengidentifikasi jenis buta warna tersebut dengan memberikan warna pada angka dan warna latarbelakangnya.

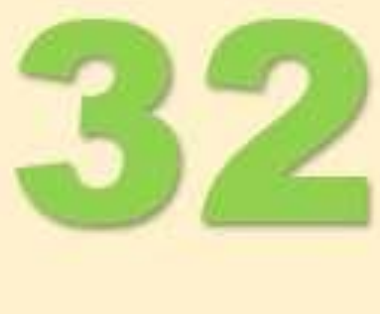

Gambar 2.2. Identifikasi Jenis Buta Warna Deuteranopia

Gambar 2.2 merupakan angka 32 dengan warna hijau yang latar belakangnya warna krem. 


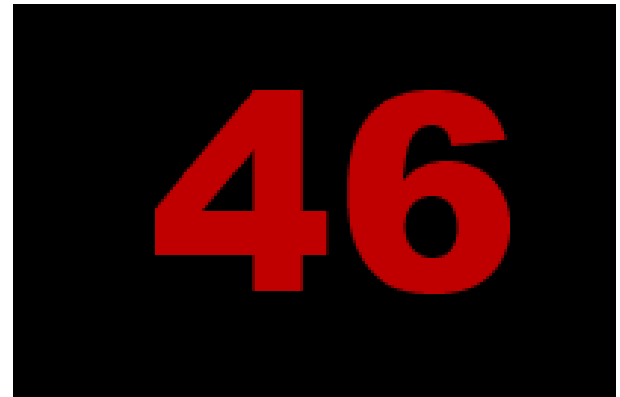

Gambar 2.3. Identifikasi Jenis Buta Warna Protanopia

Gambar 2.3 merupakan angka 46 dengan warna merah yang latar belakangnya warna hitam.

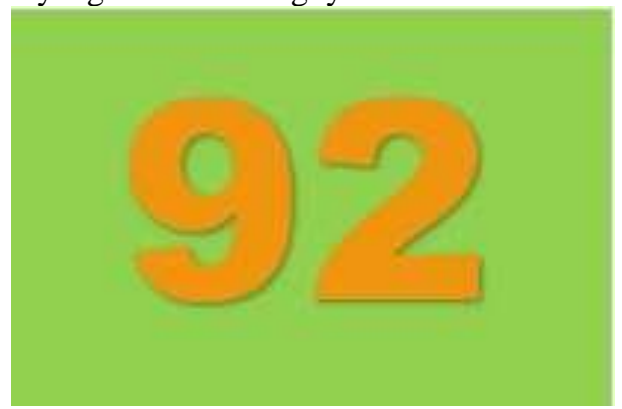

Gambar 2.4 Identifikasi Jenis Buta Warna Protanomali

Gambar 2.4 merupakan angka 92 dengan warna jingga yang latar belakangnya warna hijau.

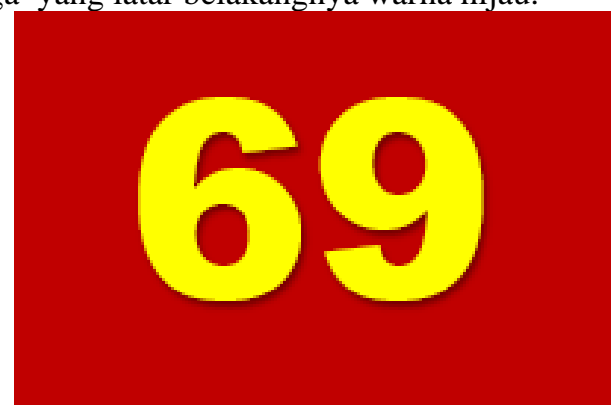

Gambar 2.5 Identifikasi Jenis Buta Warna Deuteranomali

Gambar 2.5 merupakan angka 69 dengan warna kuning yang latar belakangnya warna merah.

\subsection{Perancangan Tes Buta Warna Metode} Ishihara

Identifikasi jenis buta warna dengan metode ishihara menggunakan 21 plat dapat diketahui jenis buta warna menurut pakar dr. Ade Shynta Amelia, Sp.M [4]. Dari 21 plat tersebut dikategorikan 3, yaitu pertama mata normal dengan hasil tes 5 sampai 21 benar, buta warna parsial 2 sampai 4 benar, dan 0 sampai 1 benar buta warna total.

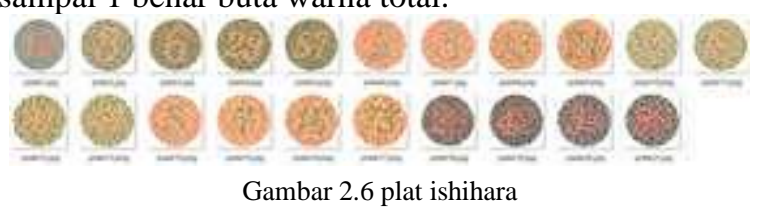

\subsection{Data Traning Deteksi Warna Objek}

Penentuan nilai HSV dilakukan dengan cara trial and erorr artinya dilakukan pengetesan beberapa kali terhadap warna yang akan dideteksi.

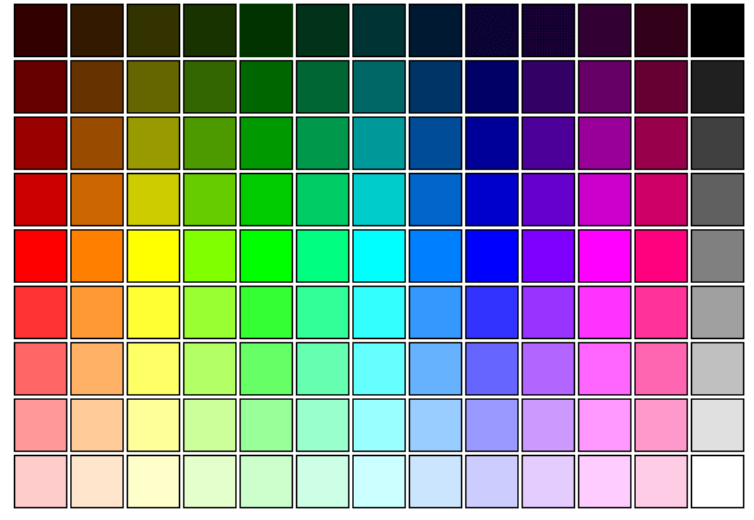

Gambar 2.7. Varian Warna [8]

Gambar 2.7 merupakan varian warna yang akan diujicobakan diambil pada situs www.rapidtables.com/web/color/RGB_Color.html.

Beberapa warna yang akan diujicobakan diantara merah, jingga, kuning, hijau, biru dan ungu. Tidak hanya pada fokus pada 1 titik tertentu, dengan nilai low dan high pada warna dapat menentukan jarak warna yang dideteksi.

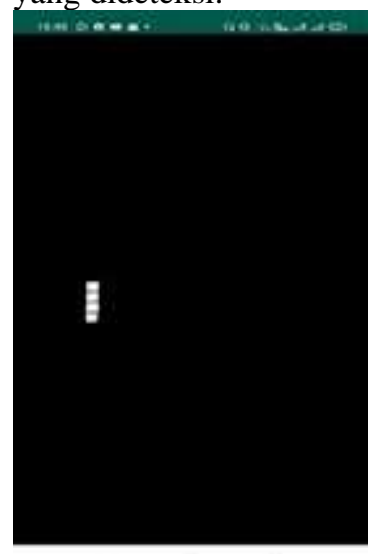

(A) Merah

(C) Kuning

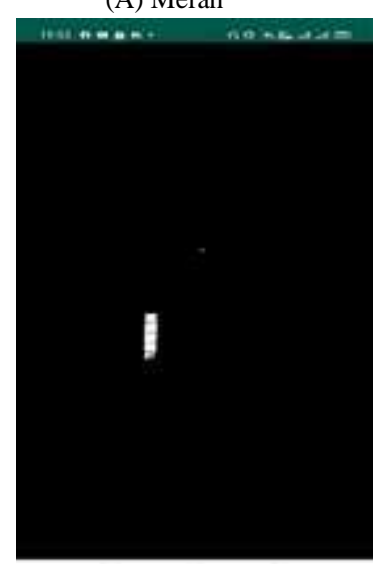

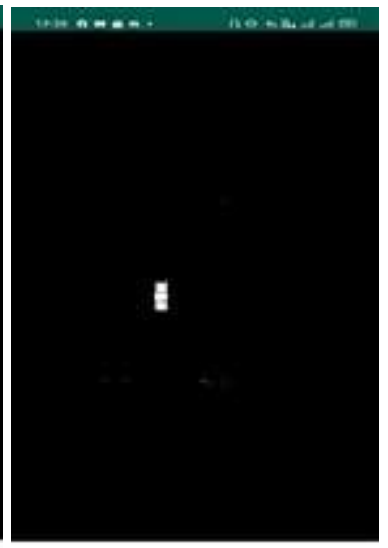

(B) Jingga

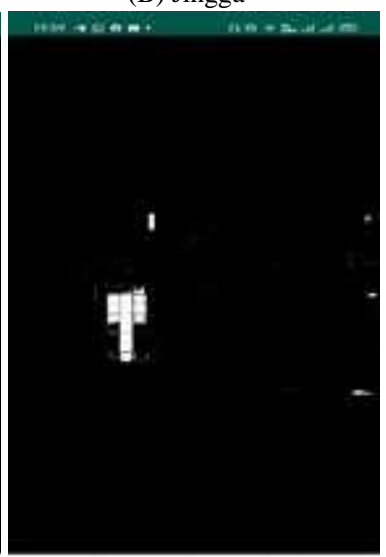

(D) Hijau 


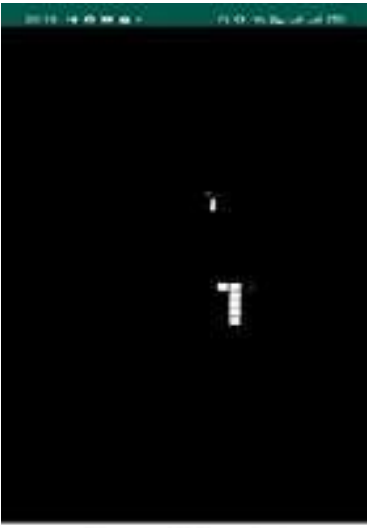

(E) Biru

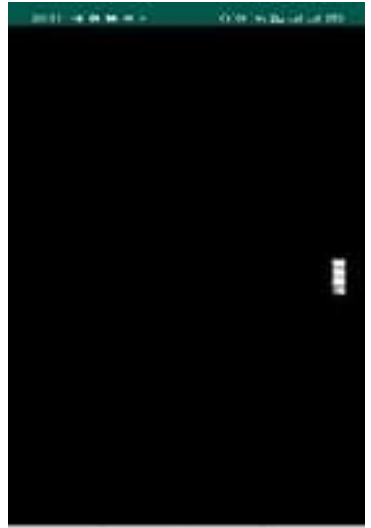

(F) Ungu
Gambar 2.8. Hasil Data Training Deteksi Warna

Gambar 2.8 merupakan hasil data training deteksi warna.

Tabel 1. Nilai HSV Data Training

\begin{tabular}{ccc}
\hline warna & scalar low & scalar high \\
\hline Merah & $115,100,100$ & $125,255,255$ \\
Jingga & $100,100,100$ & $110,255,255$ \\
Biru & $0,100,100$ & $10,255,255$ \\
Hijau & $60,100,100$ & $80,230,230$ \\
Kuning & $85,100,100$ & $95,255,255$ \\
Ungu & $170,100,100$ & $180,255,255$ \\
\hline
\end{tabular}

\section{HASIL DAN PEMBAHASAN}

\subsection{Hasil Penelitian}

Berdasarkan perancangan yang ada, aplikasi ini mempunyai 2 identifikasi buta warna dan deteksi warna gambar atau objek. Selain itu aplikasi ini juga mempunyai penjelasan jenis buta warna parsial yang ada pada menu utama.

Dalam penelitian ini aplikasi dibuat untuk dapat mengidentifikasi buta warna pada orang yang mengalami buta warna, aplikasi juga dapat mendeteksi warna gambar atau objek secara real-time.

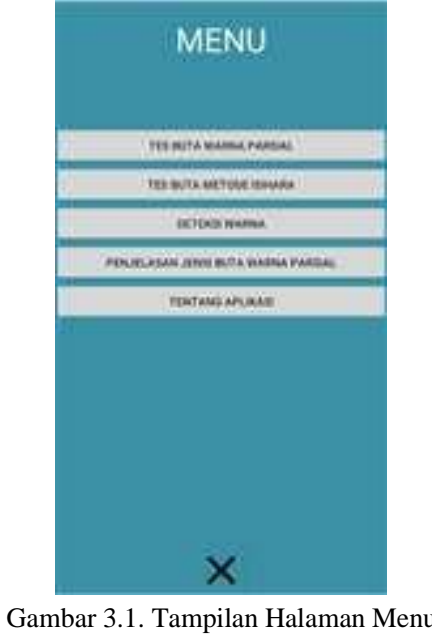

Halaman utama yang diakses oleh pengguna ketika membuka aplikasi diantaranya tes buta warna parsial, tes buta metode ishihara, deteksi warna, penjelasan jenis buta warna parsial dan tentang aplikasi.

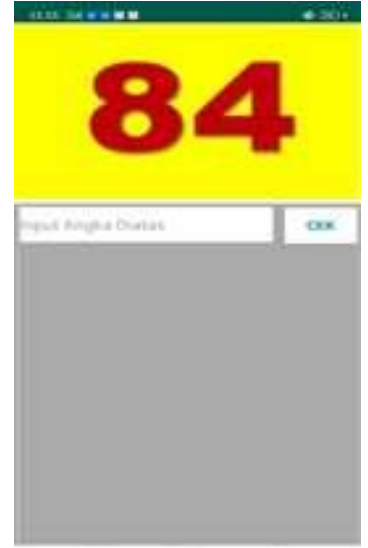

Gambar 3.2. Halaman Tes Buta Warna Parsial

Gambar 3.2 menampilkan angka yang akan dinput oleh pengguna. Ketika pengguna menginput angka yang salah dengan angka yang tertera maka menampilkan pemberitahuan kepada pengguna jenis buta warna yang mereka alami. Aplikasi juga mengarahkan pengguna untuk mendeteksi objek disekitarnya.

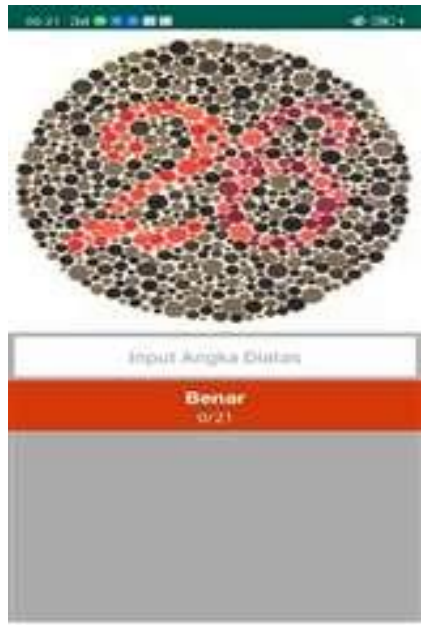

Gambar 3.3. Halaman Tes Buta Metode Ishihara

Gambar 3.3 menampilkan gambar angka dengan metode ishihara, pengguna menginput sesuai angka pada gambar. Sebanyak 21 plat ishihara yang diujikan, dan dikategorikan 1 benar adalah buta warna total, 2 sampai 4 benar adalah buta warna parsial, 5 sampai 21 benar adalah mata normal.

\subsection{Pengujian Deteksi Warna pada Gambar atau Objek.}

Setelah mendapatkan nilai dari data traning pada tabel.1 Berikut ini dilakukan beberapa pengujian deteksi dari beberapa warna.

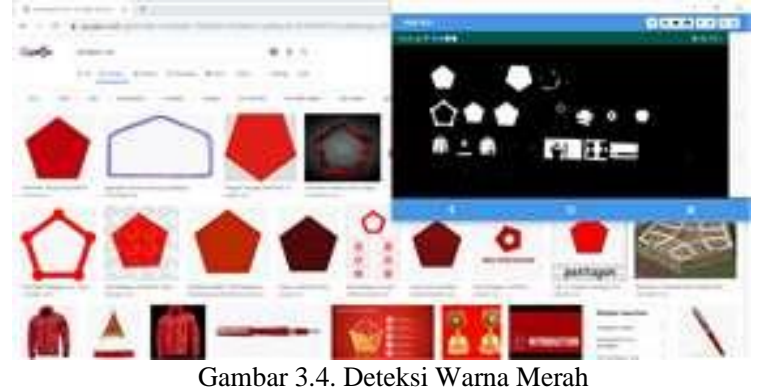



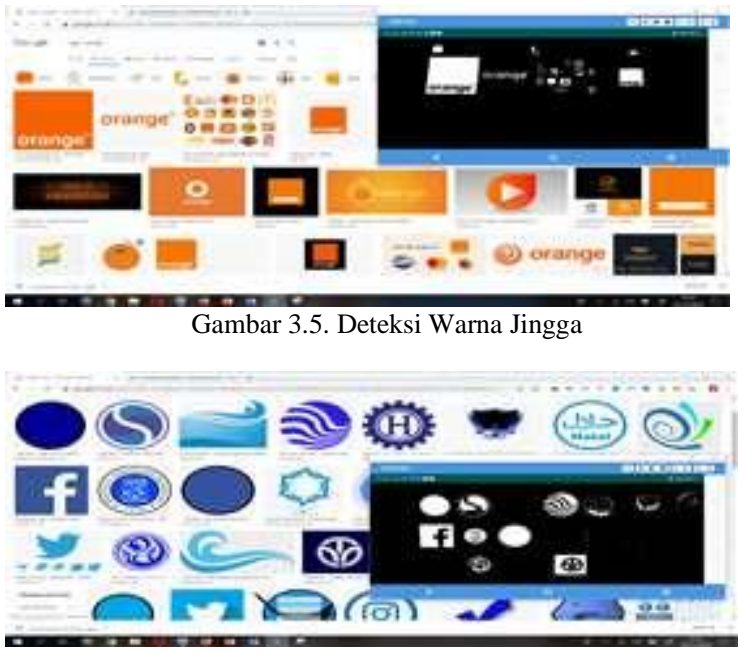

Gambar 3.6. Deteksi Warna Biru

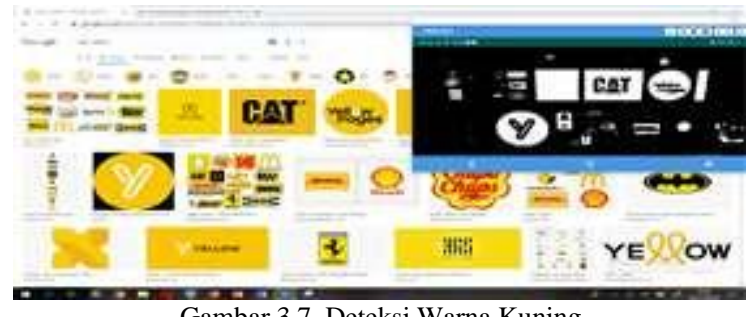

Gambar 3.7. Deteksi Warna Kuning

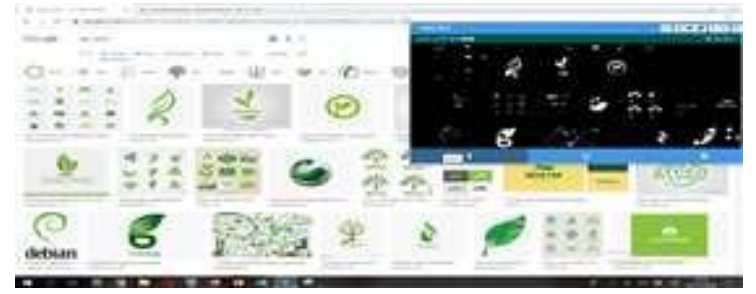

Gambar 3.8. Deteksi Warna Hijau

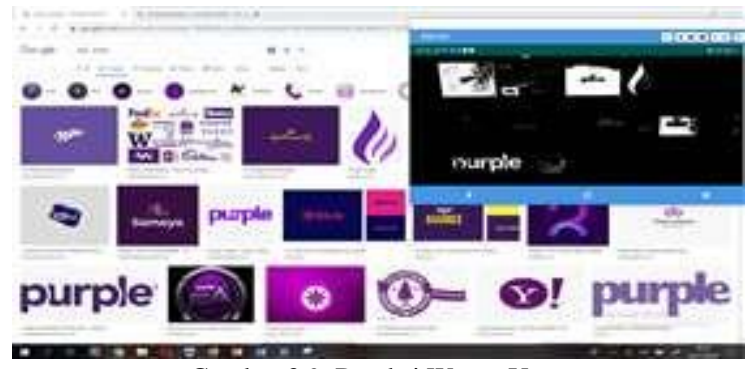

Gambar 3.9. Deteksi Warna Ungu

Berdasarkan gambar 3.4 sampai $3.9, \quad 100 \%$ aplikasi dapat mendeteksi warna yang yang sesuai. Keberhasilan deteksi warna juga dipengaruhi oleh cahaya disekitar gambar atau objek.

\subsection{Uji Aplikasi Kepada Pengguna}

Pengujian aplikasi terhadap pengguna dilakukan secara langsung dengan orang yang mengalami buta warna. Hal ini dilakukan untuk mengetahui apakah sistem yang telah dibuat dapat membantu dalam mengenali warna dan mengetahui jenis buta warna.

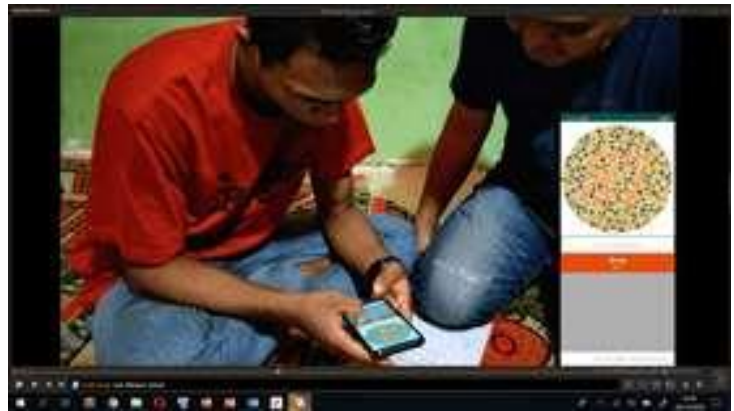

Gambar 3.4. Uji Identifikasi Buta Warna Menggunakan Metode Ishihara Kepada Pengguna

Pada Gambar 3.4. pengguna aplikasi melakukan identifikasi buta warna menggunakan metode ishihara. Aplikasi bantu buta warna menyediakan 21 plate isihara untuk membantu pengidap buta warna mengindetifikasi buta warna yang dialaminya.

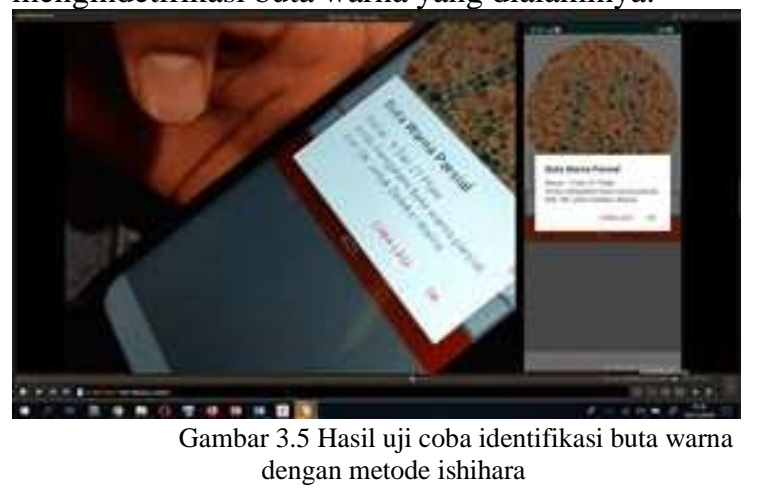

Pada Gambar 3.5. pengguna aplikasi melakukan identifikasi buta warna menggunakan metode ishihara.

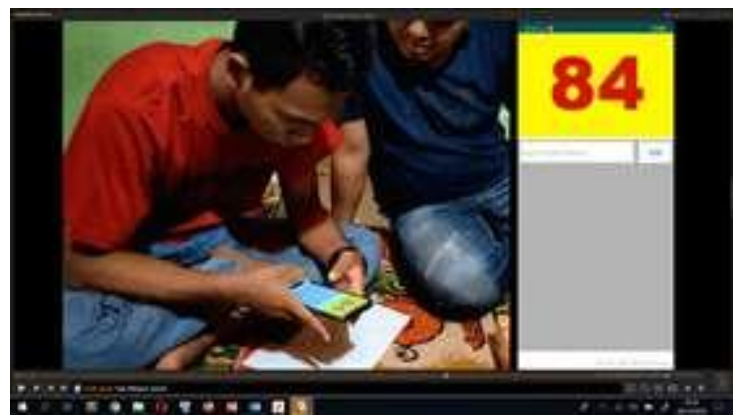

Gambar 3.6. Uji Identifikasi Buta Warna Buta Parsial

Gambar 3.6 pengguna aplikasi melakukan identifikasi buta warna parsial. Aplikasi menyediakan 12 gambar angka yang berwarna untuk mengidentifikasi jenis buta warna parsial.

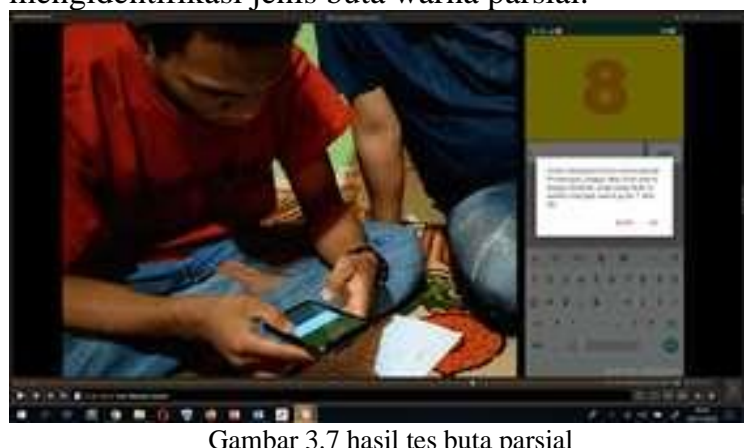


Gambar 3.7 merupakan hasil tes buta parsial, pengguna aplikasi akan mendapatkan notifikasi atau pemberitauan jika mengalami kesalahan inputan. Notifikasi tersebut seperti "Anda mengalami buta warna parsial Protanopia Jingga, Mau lihat warna jingga disekitar anda yang akan di seleksi menjadi warna putih?. Ok".

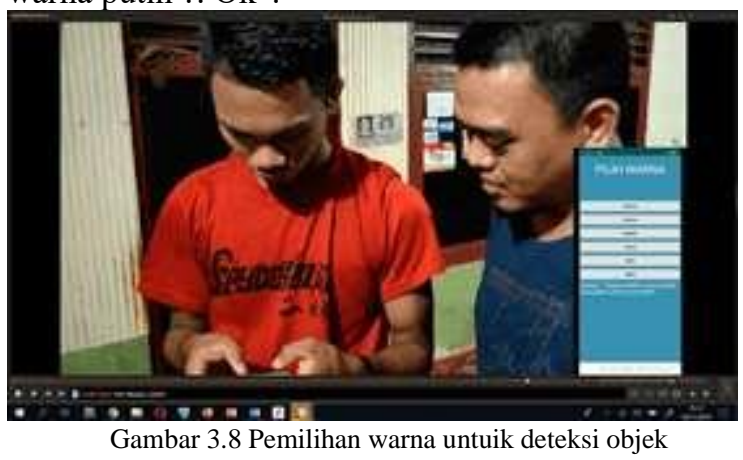

Gambar 3.8 pengguna melakukan pemilihan warna yang akan dideteksi.

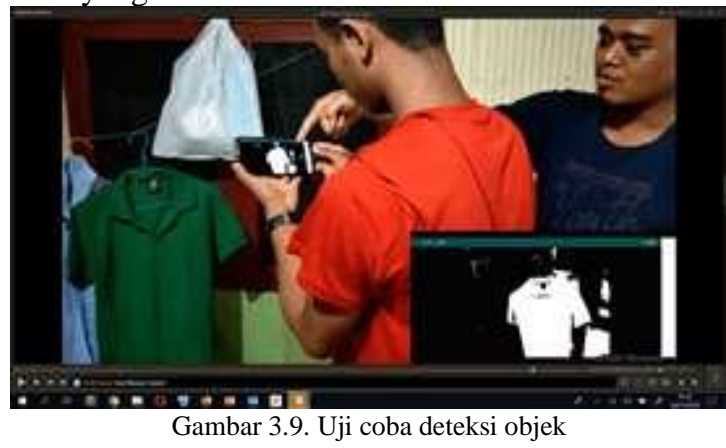

Gambar 3.9 pengguna melakukan uji coba deteksi objek yang berdasarkan warna yang telah dipilih sebelumnya.

\subsection{Pengujian Fungsional Aplikasi Bantu Buta} warna

Tabel 1. Rancangan Analisis Komputasi

\begin{tabular}{|c|c|c|}
\hline fungsional & $\begin{array}{c}\text { hasil yang } \\
\text { diharapkan }\end{array}$ & hasil \\
\hline $\begin{array}{c}\text { Klik Button } \\
\text { Tes Buta } \\
\text { Warna Parsial }\end{array}$ & $\begin{array}{c}\text { Menampilkan } \\
\text { halaman Tes } \\
\text { Buta Warna } \\
\text { Parsial }\end{array}$ & $\begin{array}{c}\text { [x] sukses } \\
\text { [ ] gagal }\end{array}$ \\
\hline $\begin{array}{c}\text { Klik Button } \\
\text { Tes Buta } \\
\text { Warna } \\
\text { Metode } \\
\text { Ishihara }\end{array}$ & $\begin{array}{c}\text { Menampilkan } \\
\text { halaman Tes } \\
\text { Buta Warna } \\
\text { Metode } \\
\text { Ishihara }\end{array}$ & $\begin{array}{c}{[\mathrm{x}] \text { sukses }} \\
{[\text { ] gagal }}\end{array}$ \\
\hline $\begin{array}{l}\text { Klik Klik } \\
\text { Button } \\
\text { Deteksi } \\
\text { Warna }\end{array}$ & $\begin{array}{l}\text { Menampilkan } \\
\text { halaman } \\
\text { sesuai warna } \\
\text { yang dipilih }\end{array}$ & $\begin{array}{c}\text { [x] sukses } \\
\text { [ ] gagal }\end{array}$ \\
\hline $\begin{array}{c}\text { Klik Button } \\
\text { Warna Merah, } \\
\text { Jingga, } \\
\text { Kuning, } \\
\text { Hijau, Biru, }\end{array}$ & $\begin{array}{l}\text { Menampilkan } \\
\text { halaman } \\
\text { sesuai warna } \\
\text { yang dipilih }\end{array}$ & $\begin{array}{c}\text { [x] sukses } \\
\text { [ ] gagal }\end{array}$ \\
\hline $\begin{array}{l}\text { Klik Button } \\
\text { Penjelasan } \\
\text { Jenis Buta } \\
\text { Warna Parsial }\end{array}$ & $\begin{array}{c}\text { Menampilkan } \\
\text { halaman } \\
\text { Jenis-jenis } \\
\text { Buta Warna } \\
\text { Parsial }\end{array}$ & $\begin{array}{c}{[\mathrm{x}] \text { sukses }} \\
\text { [] gagal }\end{array}$ \\
\hline
\end{tabular}

\begin{tabular}{ccc} 
Klik Button & $\begin{array}{c}\text { Menampilkan } \\
\text { halaman }\end{array}$ & [x] sukses \\
Tentang & Tentang & {[] gagal } \\
Aplikasi & Aplikasi & \\
\hline
\end{tabular}

\section{KESIMUPLAN DAN SARAN}

Berdasarkan analisa dan hasil pengujian aplikasi bantu buta warna, dapat ditarik kesimpulan $100 \%$ dapat mendeteksi warna merah, jingga, kuning, hijau, dan ungu. keberhasil deteksi warna dipengaruhi oleh cahaya disekitar gambar atau objek. Tes buta warna parsial menggunakan 12 angka yang diberi warna, sedangkan Tes buta warna metode ishihara menggunakan 21 plat. Berdasarkan pengujian langsung terhadap orang yang mengalami buta warna, aplikasi dapat mengidentifikasi jenis buta warna.

Aplikasi ini membutuhkan pencahayaan yang baik agar pengambilan warna objek dapat lebih baik. Diharapkan dapat mendeteksi warna lebih dari 6 warna dasar. Diharapkan aplikasi tidak hanya digunakan oleh pengidap tetapi berguna pula bagi semua orang.

\section{DAFTAR PUSTAKA}

[1] Halodoc, 2020. "Buta Warna". Tersedia [www.halodoc.com/kesehatan/buta-warna] diakses 16 Februari 2020.

[2] T. Foraldy., 2019. "Buta Warna Tak Selalu Hitam dan Putih: Mengenal Jenis-Jenis Buta Warna". Tersedia [www. hellosehat.com/hidupsehat/kesehatan-mata/berbagai-jenis-buta-warna] diakses 16 Febuari 2020.

[3] K. Andrian., 2019. "Hal-Hal yang Perlu Anda Ketahui Seputar Tes Buta Warna Parsial". Tersedia [www.alodokter.com/tes-buta-warnaparsial-untuk-mengetahui-jenis-kelainanmelihat-warna] diakses 16 Februari 2020.

[4] A. Octaviano., and A. Umbari., 2017. 'Penerapan Metode Ishihara Untuk Mendeteksi Buta Warna Sejak Dini Berbasis Android', Jurnal Informatika Universitas Pamulang, Vol. 2, No. 1, pp. 42-50

[5] I. W. P. S. Windusara., and A. Y. Husodo., A. Zubaidi., 2018. 'Sistem Pakar Buta Warna Menggunakan Bangun Ruang Berbasis Mobile Dengan Sistem Operasi Android', J-COSINE, Vol. 2, No. 1, pp.54-63

[6] G. Y. Swara., 2019. 'Implementasiaugmented Reality Sebagai Alat Bantu Pada Penderita Buta Warna Berbasis Android', Jurnal TEKNOIF, Vol. 7 No. 1, pp. 48-57

[7] R. Pratama, A. Fuad, dan F. Tempola, 2019. 'Deteksi Kematangan Buah Tomat Berdasarkan Fitur Warna Menggunakan Metode Tansformasi Ruang Warna His', JIKO (Jurnal Informatika dan Ilmu Komputer), Vol. 2, No. 2, pp. 81-86.

[8] A. N. Hermana., A. Zulkarnain., dan Y. A. Riadi., 2018. 'Implementasi Pengolahan Model Warna RGB Pada Aplikasi Identifikasi Warna’, MIND Journal, Vol. 3, No. 1, pp. 49-60

[9] J. F. Fauzi., H. Tolle., dan R. K. Dewi., 2019. 'Implementasi Metode RGB To HSV pada 
Aplikasi Pengenalan Mata Uang Kertas Berbasis Android untuk Tuna Netra', Jurnal Pengembangan Teknologi Informasi dan Ilmu Komputer, Vol. 2, No.6, pp. 2319-2325

[10] Rapidtables, 2020. "RGB Color Codes Chart". Tersedia [www.rapidtables.com/web/color/RGB_Color.ht ml] diakses 16 Februari 2020. 